\title{
Study on Steel and polypropylene hybrid fiber reinforced concrete- A review
}

\author{
M.Sriram ${ }^{1}$, K.R. Aswin Sidhaarth ${ }^{2}$ \\ Research Scholar, Vel Tech RR Dr.Sagunthala R\&D Institute of Science \& Technology, \\ Chennai ${ }^{1}$. \\ Associate Professor, Vel Tech RR Dr.Sagunthala R\&D Institute of Science \& Technology, \\ Chennai2
}

\begin{abstract}
Increasing demand and inadequate materials availability leads the researchers to find alternate materials. In general, hybrid fiber is nothing but mixture of two or more fibers. In this review, various properties of steel fibers and polypropylene fibers were studied. In order to study the physical and mechanical properties of steel fiber, polypropylene fiber and other materials used in concrete, various tests such as Slump cone test, Compaction factor, Compressive strength, flexural strength etc., were used. Hybrid fibers have the tendency to control cracks at different levels. Workability of concrete get reduced due to more addition of steel fibers.The addition of steel fiber and polypropylene fiber results in an increase of 12 to $14.30 \%$ compressive strength, 33 to 36.6\% increase in flexural strength and 9 to $10.16 \%$ increase in split tensile strength. Addition of most favorable amount 0.9 to $1 \%$ of steel fiber and 0.9 to $1 \%$ of polypropylene fiber gives maximum compressive strength up to 41.67 to 42.68\%. Split tensile strength increases by increasing the fiber content in concrete but workability decreases when steel fiber content is increased in concrete.
\end{abstract}

Keywords: Steel fibers, polypropylene fibers, Split tensile, Workability

\section{Introduction}

Concrete is a material which is commonly used in construction. In that there are different types of concrete which is used based on that particular site conditions and locations. Concrete made by using Portland cement has particular characteristics. Concrete is highly strong in compression but weak in tension and tends to be brittle. Because of these weaknesses uses of concrete is limited. One more weakness of concrete is that cracks forms when concrete is placed before it is properly hardened [6]. Cracks are major causes of weakness in concrete particularly in major constructions leads to structural failure and durability reductions. Concrete is generally weak in tension and it is overcome by the usage of reinforcement and by the certain volume of fibers[7-9]. Fiber reinforcement is mostly used for controlling the cracks formation and it is not for structural strengthening. The cracks formation may get reduced by the addition of polypropylene fibers and toughness ,impact resistance increases by the addition of steel fibers [10-13]. If we are using hybrid fibers, we may increase all the properties of concrete. Compressive, flexural behavior and morphological properties of hybrid fiber reinforced concrete using the combination of steel and polypropylene fibers were studied. 


\section{Reviews from Literatures}

In common practices, concrete is obtained by mixing cementitious substances, water, aggregate (fine and coarse) and occasionally admixtures in required proportions. Freshly mixed material is known as fresh concrete which can be moulded into any desired shape and later it will form as a rock-like mass known as hardened concrete [13-15]. The chemical reaction between cement and water results in hardening, it continues for long time to become stronger with age. Nowadays the most commonly used construction material is Cement mortar and concrete made with Portland cement. The above said material is naturally brittle and has some drawbacks such as poor deformability. Tensile strength and flexural strength is relatively low, compared with compressive strength. Concrete which containing fibrous material is termed as Fiber Reinforced Concrete and these fibrous material increases its structural integrity [17-19]. The failure mode was more ductile by using the fibers and also increases its tensile strength. There are different types of fibers in synthetic fibers (Steel fibers,Polypropylene fibers, glass fibers etc.) and natural fibers (Coconut coir fiber, Cottonfiber, Sisal fibers etc.) each of which gives varying properties to the concrete. In addition, the types of fiber materials used, geometries, distribution, orientation, and densities may change the character of fiber reinforced concrete. In general, two or more different types of fibers are rationally combined to produce a composite, in that it may derives benefit from individual fiber and exhibits a synergistic response [20-22]. In order to improve the properties of concrete, we may add with the combination of metallic and non-metallic fibers and it may offers advantages in improving the properties.

By bridging actions, fibers used in the concrete have the ability to prevent cracks which forms in the surface. In order to obtain the hybrid fibers, combination of two or more different types of fibers is becoming more common. The performance of hybrid fibers exceeds the performance induced by each fiber type.

Basically fibers are of two groups; Modulus of fibers which is lower than the cement matrix such as cellulose, nylon, polypropylene etc. Modulus of fibers which is higher than the cement such as asbestos, glass, steel etc.

Strain performance is expected to enhance by the fibers having lower modulus of elasticity where as strength performance is expected to enhance by the fibers having higher modulus of elasticity. Moreover, the concrete becomes more homogeneous and isotropic by the addition of hybrid fibers and therefore it is changed from brittle to more ductile material.

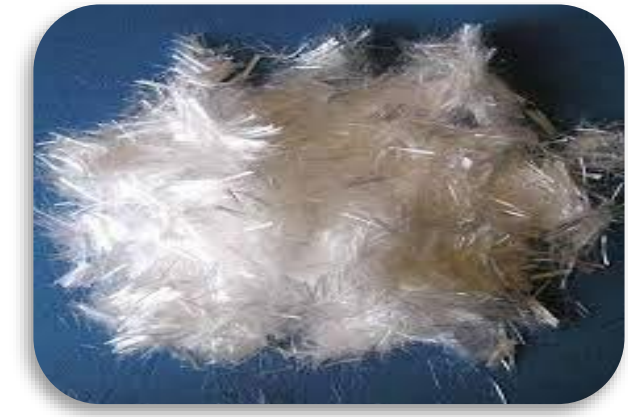

a)Polypropylene fibers

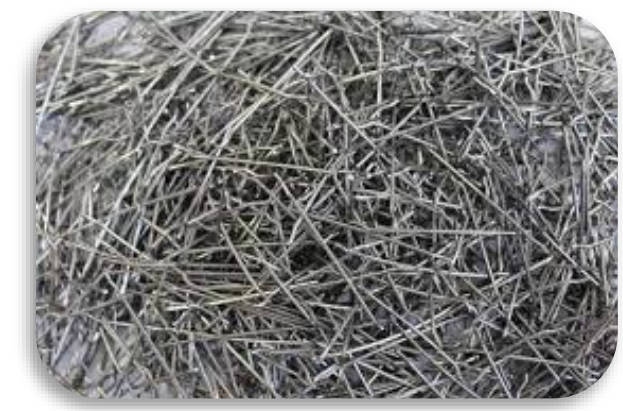

b) Steel fibers 
Growth in constructions has created a huge requirement for various types of concrete mixes which are required to have high strength, hardness, toughness and durability. Self compacting concrete, high strength concrete, high performance concrete, geopolymer concrete are few some examples of new types of concrete. Fiber reinforced concrete has the ability to reduce the damages and also minimizes the cracks formation[18-20]. For the production of special concretes, different types of fibers are used. In general fibers are of two types Natural fibers and synthetic fibers. These additions of fibers enhance the mechanical, physical and durability properties of concrete [13-18].

In general,polymers, metals, ceramics and other products are used for production of resins. This combination has led to the development of various classic materials such as glass fiber reinforced concrete, carbon fiber reinforced concrete, basalt fiber reinforced concrete and some modernly improved polyethylene naphthalate and polyethylene terephthalate composites [20-23]. The behavior of fiber reinforced polymer may vary significantly based on the types of fiber and polymer matrix. Fig.1 shows the comparison of stress-strain curve of various fiber reinforced polymers.

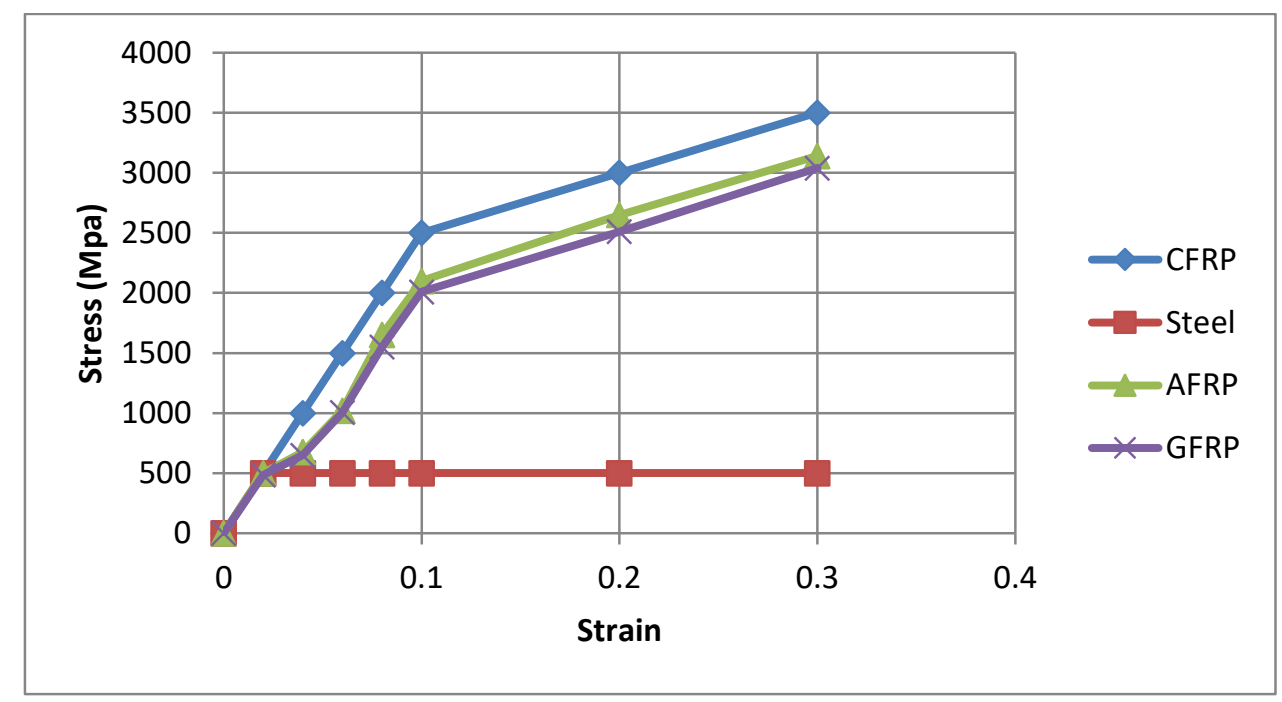

Fig.1. Shows the relations between stress and strain for various FRPs [41-45]

In order to make stronger in both the existing and newly constructed buildings, usage of fiber reinforced concrete plays a major role. Hybrid use of fibers at different proportions has been effectively improving the post cracking strength,flexural toughness.

The results of hybrid fiber reinforced concrete performances exceed the individual fibers performance because of their positive interactions between the fibers. HFRC is obtained from a combination of two or more different types of fibers, which may differ in their properties, remain bonded together when added in concrete and retain their identities and properties. Till now combinations of polypropylene-carbon, carbon-steel and steelpolypropylene fibers hybrid composites have been used by the researchers. Table1, shows Physical and mechanical properties of Natural fibers. 
Table 1- Shows Physical and mechanical properties of Natural fibers

\begin{tabular}{|c|c|l|c|c|c|c|}
\hline Fiber & $\begin{array}{l}\text { Diameter } \\
\boldsymbol{\mu m}\end{array}$ & $\begin{array}{l}\text { Density } \\
\mathbf{g} / \mathbf{c m 3}\end{array}$ & $\begin{array}{l}\text { Young's } \\
\text { Modulus GPa }\end{array}$ & \% of Elongation & $\begin{array}{l}\text { Tensile } \\
\text { strength MPa }\end{array}$ & References \\
\hline Coir & 17.5 & 1.2 & 6 & $15-30$ & 175 & {$[20]$} \\
\hline Hemp & 19 & 1.47 & 70 & $2-38$ & 690 & {$[20]$} \\
\hline Sisal & 21 & $1.33-1.5$ & 9.2 & $2-2.5$ & $511-635$ & {$[20]$} \\
\hline Jute & 18.4 & $1.3-1.46$ & $10 .-30$ & $1.5-1.8$ & $393-773$ & {$[35]$} \\
\hline Flax & 20 & $1.4-1.5$ & $27.6-80$ & $1.2-3.2$ & $345-1500$ & {$[35]$} \\
\hline Cotton & 14.5 & $1.5-1.6$ & $5.5-12.6$ & $3-10$ & $287-597$ & {$[35]$} \\
\hline Banana & $12-13$ & 1.35 & 12 & $1.5-9$ & 500 & {$[39]$} \\
\hline Pineapple & 50 & 1.4 & $34.5-82.5$ & 2 & $413-2627$ & {$[39]$} \\
\hline
\end{tabular}

Table 2 - Physical and Mechanical Properties of Artificial fibers

\begin{tabular}{|c|c|c|c|c|c|c|}
\hline Fiber & $\begin{array}{l}\text { Diameter } \\
\boldsymbol{\mu m}\end{array}$ & $\begin{array}{l}\text { Density } \\
\text { g/cm3 }\end{array}$ & $\begin{array}{l}\text { Young's } \\
\text { Modulus Gpa }\end{array}$ & \% of Elongation & $\begin{array}{l}\text { Tensile } \\
\text { strength MPa }\end{array}$ & References \\
\hline Carbon & $7-10$ & 1.4 & 230 & $1.4-1.8$ & 4000 & {$[5]$} \\
\hline Glass & 10 & 2.5 & 70 & 3 & 2400 & {$[5]$} \\
\hline E-Glass & 10 & $2.5-2.6$ & $70-76$ & $2.5-2.6$ & $2000-3500$ & {$[5]$} \\
\hline Aramid & - & 1.4 & $63-67$ & $3.3-3.7$ & $3000-3150$ & {$[5]$} \\
\hline Polypropylene & 100 & 0.9 & 8 & 8.1 & 800 & {$[73]$} \\
\hline Steel & 500 & 7.8 & 200 & 3.2 & 1500 & {$[73]$} \\
\hline
\end{tabular}

Concrete blocks with addition of steel fibers increased its compressive strength by $8.78 \%$ and tensile strength by $25.90 \%$. Flexural strength increases by $57.20 \%$ with the addition of Metakaolin and steel fiber.Flexural strength increases gradually with the addition of metakaolin.[58]
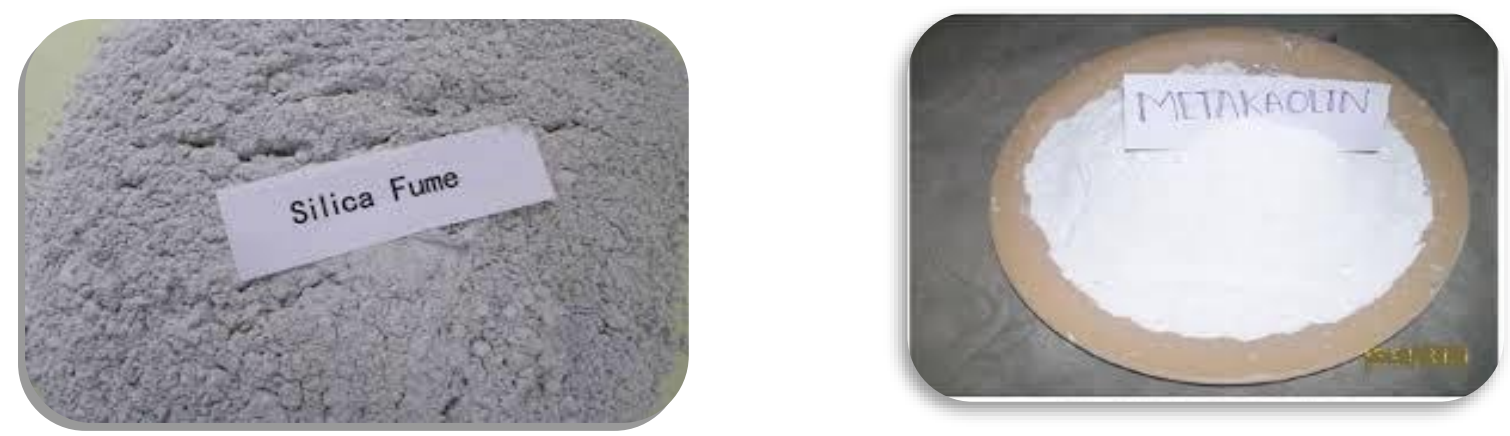

The Kaolin can satisfy the world demand for filler, paper and ceramic industries. Metakaolin (MK) is obtained after some suitable thermal treatment. Metakaolin can be used in mortar and concrete, it will improve their properties [53].

There are too many alternatives materials for cement available in market.Compared with silica -fume modified concrete ,metakaolin-modified concrete showed a better workability. The strength of the metakaolin-modified concrete increased at all ages similarly to that of the silica fume-modified concrete as the replacement level increases [15]. 
Table -3 Properties of cement and Metakaolin

\begin{tabular}{|l|l|l|l|}
\hline Chemical Properties & Items & Cement & Metakaolin \\
\hline & $\mathrm{CaO}(\%)$ & 61.60 & 0.5 \\
\hline & $\mathrm{SiO}_{2}(\%)$ & 19.43 & 53 \\
\hline & $\mathrm{Al}_{2} \mathrm{O}_{3}(\%)$ & 5.64 & 43 \\
\hline & $\mathrm{Fe}_{2} \mathrm{O}_{3}(\%)$ & 4 & 1.2 \\
\hline & $\mathrm{MgO}(\%)$ & 2.41 & 0.4 \\
\hline & $\mathrm{LOI}(\%)$ & 1.85 & 0.4 \\
\hline & $\mathrm{SO}_{3}$ & 2.94 & - \\
\hline & $\mathrm{K}_{2} \mathrm{O}$ & 0.78 & - \\
\hline & $\mathrm{Na}_{2} \mathrm{O}$ & 0.11 & - \\
\hline Physical Properties & $\mathrm{Specific} \mathrm{gravity}$ & 3.19 & 2.60 \\
\hline & Fineness (m2/kg) & 328 & 18,000 \\
\hline
\end{tabular}

Table 4 shows the physical and chemical analysis of silica fume

\begin{tabular}{|l|l|l|l|}
\hline Chemical Analysis & Content & Analysis & References \\
\hline & Sio2 & $95 \%$ & {$[56]$} \\
\hline & SO3 & $0.18 \%$ & {$[56]$} \\
\hline & $\mathrm{Cl}$ & $0.12 \%$ & {$[56]$} \\
\hline & Total Alkali & $0.66 \%$ & {$[56]$} \\
\hline & Moisture content & $0.16 \%$ & {$[56]$} \\
\hline & Loss of ignition & $1.92 \%$ & {$[56]$} \\
\hline Physical Analysis & pH & 7.90 & {$[56]$} \\
\hline & $\begin{array}{l}\text { Density - Specific } \\
\text { gravity }\end{array}$ & 2.27 & {$[56]$} \\
\hline & Bulk Density & $187.91 \mathrm{~kg} / \mathrm{m} 3$ & {$[56]$} \\
\hline & Specific surface area & $22.21 \mathrm{~kg} / \mathrm{m} 2$ & {$[56]$} \\
\hline
\end{tabular}

The steel fiber reinforced concrete and plain concrete specimens were prepared. In order to get stress-strain curves different types of tests have been done and we may compare with the conventional concrete model results to evaluate the actual stress-strain relations of FRC[4].By conduct several investigations, the mechanical behavior of conventional concrete and Steel fiber reinforced concrete has been studied and developed. In multi axial stress state, an investigational study has been performed on the strength and stress-strain relations of SFRC [78]. Compared with plain concrete, polypropylene fiber reinforced concrete is a more sound concrete. In concrete production, by replace the cement with fly ash reduces a environmental effects and also addition of polypropylene fibers has reduces the chloride attack by $24.4 \%$ to $24.9 \%$. The addition of $0.35 \%$ to $0.45 \%$ polypropylene fibers has reduced the chloride attack by $24.6 \%$ to $24.9 \%$. Addition of $58 \%$ to $61 \%$ fly ash has demonstrated that the chloride attack was reduced by $39 \%$ to $41 \%$. Based on the experimental study the maximum allowable limit for RAC with $0.9 \%$ to $1 \%$ PP fiber is $49 \%$ to $51 \%$. For 
100\% RAC with 1\% PP fiber, compressive strength, splitting tensile strength and shear strength increases by $15.66 \%$ to $15.69 \% 34.83 \%$ to $34.87 \%$ and $38.30 \%$ to $38.33 \%$ respectively when compared with reference mix proportion[23]. In Fiber reinforced concrete numerous admixtures were used, in that the optimal estimations of polypropylene, silica smoke and RHA were determined for various mix proportion. Its values are $0.9 \%$ to $1.1 \%$ of polypropylene, $7.3 \%$ to $7.6 \%$ of silica smoke and $14.85 \%$ to $15.1 \%$ of RHA. By adding fibers in concrete increases the flexural ability of the concrete [66].

Increased fiber content in concrete, results in workability reduction in both types of fibers based on sizes (Micro and Macro fibers) . Micro synthetic fibers (Small in size) have the ability to provide superior resistance to the formation of plastic shrinkage [51]. It is available in standard length $(11-20 \mathrm{~mm})$ with typical dosage rates varying from $(0.3-0.9 \mathrm{~kg} / \mathrm{m} 3)$ depending on the nature of work.

Macro synthetic fibers can also provide resistance to the formation of plastic shrinkage and also provide concrete with toughness and durability. It is available in standard length (37$51 \mathrm{~mm})$ with typical dosage rates varying from $(1.6-9.2 \mathrm{~kg} / \mathrm{m} 3)$ depending on the nature of applications.

Hybrid fiber concrete(HFC) which contains steel fiber and the ultra-high molecular weight polyethylene (UHMWPE) fiber were inspected to determine the mechanical properties . UHMWPE fiber is added $0.3 \%$ to $0.35 \%$ in excess, the tensile strength increases by 13.61 to $13.65 \%$ and the compressive strength increases by 15.47 to $15.49 \%$ [42].

The river sand was completely used and it was insufficient for future constructions. Fiber is generally added in concrete to improve their properties. Adding fibers in concrete, will increase the lifetime of the structure by reducing the cracks formations [46].

Introducing mineral admixtures in concrete may enhance their brittleness. In order to make materials with high tensile strength, ductility, toughness and improved durability properties fibers are often included into cementitious concrete [63-67]. While preparing concrete mix design, it is more essential consider the influence of each aspect.

\section{APPLICATIONS}

Polypropylene fibers are generally elastic in nature and it is majorly used in many industrial applications such as needle carpets, sanitary, household articles, home furnishing and automotive industry etc.

Polypropylene Fibers is used in Construction of concrete sleepers, concrete pavements, Machine foundations, and various off shore structures. Steel fibers reinforced concrete is used in repair of existing pavements and various highway and airfield components etc 


\section{CONCLUSIONS}

The results of the present study in hybrid fibers reinforced concrete shows the properties of fibers varies from one type of fiber to other type of fiber. The cracks formation can be minimized by the presence of fibers in concrete. Usage of PPF may minimize the permeability factor, shrinkage factor, settlement factor. Volume fraction of fibers increases, the workability of concrete may decrease.

\section{References:}

[1]A. Bentur, S. Mindess, Fibre Reinforced Cementitious Composites, CRC Press, 2006. https://doi.org/10.1201/9781482267747.

[2]Afroughsabet, V., Biolzi, L., Monteiro, P.J.M., 2018. The effect of steel and polypropylene fibers on the chloride diffusivity and drying shrinkage of highstrength concrete. Compos. B Eng. 139, 84e96.https://doi.org/10.1016/1.compositesb.2017.11.047

[3]Amir BahadorMoradikhou a, AlirezaEsparham a, Mohammad JamshidiAvanaki , Physical $\&$ mechanical properties of fiber reinforced metakaolin-based geopolymer concrete, Construction and Building Materials https://doi.org/10.1016/j.conbuildmat.2020.118965

[4]Bencardino F, Rizzuti L, Spadea G, Ramnath N Swamy 2008 Stress-Strain Behaviour of Steel Fiber-Reinforced Concrete in Compression ASCE Journal of Materials in Civil Engineering 20 (3) p 255-263

[5]Biao Li, Yin Chi, LihuaXu, Yuchuan Shi, Changning Li, Experimental investigation on the flexural behavior of steel-polypropylene hybrid fiber reinforced concrete,Construction and Building Materials , DOI:10.1016/j.conbuildmat.2018.09.202

[6]Biolzi L, Guerrini GL, Rosati G (1997) Overall structural behavior of high strength concrete specimens. Constr Build Mater 11(1):57-63 https://doi.org/10.1016/S0950$\underline{0618(96) 00026-8 .}$

[7]Bisby LA. Fire behaviour of fibre-reinforced polymer (FRP) reinforced or confined concrete. Queen's University; 2003.Composites part-b. 2520-2520.

https://doi.org/10.1016/j.compositesb.2015.05.045

[8]Brooks JJ, Johari MM, Mazloom M (2000) Effect of admixtures on the setting times of high-strength concrete. CemConcr Compos 22(4):293-301 https://doi.org/10.1016/S09589465(00)00025-1

[9]Buyukozturk $O$, Gunes $O$, Karaca E. Progress on understanding debonding problems in reinforced concrete and steel members strengthened using FRP composites. Constr Build Mater 2004;18(1):9-19 DOI:10.1016/S0950-0618(03)00094-1 
[10]Chindaprasirt P, Homwuttiwong S, Sirivivatnanon V (2004) Influence of fly ash fineness on strength, drying shrinkage and sulfate resistance of blended cement mortar. CemConcr Res 34(7):1087-1092https://doi.org/10.1016/j.cemconres.2003.11.021.

[11]Chinmaya Kumar MahapatraSudhirkumar V.Barai , Hybrid fiber reinforced self compacting concrete with fly ash and colloidal nano silica: A systematic study, Construction and Building Materials, https://doi.org/10.1016/j.conbuildmat.2017.11.131

[12]Czarnecki L, Kaproń M, Van Gemert D. Sustainable construction: challenges,contribution of polymers, research arena. Restoration Build Monuments 2013;19(2-3):81-96.DOI: https://doi.org/10.1515/rbm-2013-6583

[13]De Lorenzis L, Teng JG. Near-surface mounted FRP reinforcement: An emerging technique for strengthening structures. Compos B Eng 2007;38(2):119-43. https://doi.org/10.1016/j.compositesb.2006.08.003

[14]DebabrataPradhan, D. Dutta Influence of Silica Fume on Normal ConcreteInt. Journal of Engineering Research and Applications Vol. 3, Issue 5, Sep-Oct 2013.

[15]Ding J, Li Z. Effects of metakaolin and silica fume on properties of concrete, ACI Materials Journal, No. 4, 99(2002) 393-8.

[16]Ellyin F, Rohrbacher. Effect of aqueous environment and temperature on glassfibre epoxy resin composites. J ReinfPlast Compos 2000;19(17):1405-27. https://doi.org/10.1177/073168400772678518.

[17]ErhanGuneyisi a, \, MehmetGesog `u a, Arass Omer MawlodAkoi a, KasımMermerdas Combined effect of steel fiber and metakaolin incorporation on mechanical properties of concrete, Composites: DOI:10.1016/j.compositesb.2013.08.002

[18]Fangyu Liu abWenqiDingabYafeiQiaoab Experimental investigation on the flexural behavior of hybrid steel-PVA fiber reinforced concrete containing fly ash and slag powder, Construction and Building MaterialsVolume 228, 20 December 2019, 116706https://doi.org/10.1016/j.conbuildmat.2019.116706

[19]Fiber Reinforcements, Infrastructure Corrosion and Durability - Sustainable Study, OMICS Group eBooks, 2014.fibers on the chloride diffusivity and drying shrinkage of high strengthconcrete. Compos. B Eng. 139, 84e96.

https://doi.org/10.1016/j.compositesb.2017.11.047

[20]Flavio de Andrade Silva, NikhileshChawla, Romildo Dias Toledo Filho, Mechanical behavior of natural sisal fibers, J. Biobased Mater.Bioenergy, 4 (2010) 1-

8.DOI: $10.1166 / \mathrm{jbmb} .2010 .1074$ 
[21]Green MF, Bisby LA, Beaudoin Y, Labossiere P. Effect of freeze-thaw cycles on the bond durability between fibre reinforced polymer plate reinforcement and concrete. Can J Civ Eng 2000;27:949-59. DOI:10.1139/cjce-27-5-949

[22]H.R. Pakravan , M. Latifi , M. Jamshidi Hybrid short fiber reinforcement system in concrete: A review, Construction and Building Materials (2017)

https://doi.org/10.1016/j.conbuildmat.2017.03.059

[23]Hanumesh B M, Harish B A, N. VenkataRamana, Influence of Polypropylene Fibers onrecycled aggregate concrete. Materials Today: Proceedings 5(2016) 1147-

1155.DOI:10.1016/j.matpr.2017.11.195

[24]Hany NF, Hantouche EJ, Harajli MH. Finite element modeling of FRP-confined concrete using modified concrete damaged plasticity. Eng Struct 2016;125(15):1-14. DOI10.1016/j.engstruct.2016.06.047

[25]Hawileh RA, Naser M, Rasheed HA. Thermal-Stress finite element analysis of CFRP strengthened concrete beam exposed to top surface fire loading. Mech Adv Mater Struct 2011;18(3):172-80. DOI:10.1080/15376494.2010.499019

[26]Hawileh RA, Naser M, Zaidan W, Rasheed HA. Modeling of insulated CFRPstrengthened reinforced concrete T-beam exposed to fire. Eng Struct 2009;31(12):3072-9. DOI:10.1016/j.engstruct.2009.08.008

[27]Hollaway LC. A review of the present and future utilization of FRP composites in the Civil infrastructure with reference to their important in service properties. Constr Build Mater 2010;24(12):2419-45. https://doi.org/10.1016/j.conbuildmat.2010.04.062

[28]HuiZhong, Mingzhong Zhang Experimental study on engineering properties of concrete reinforced with hybrid recycled tyre steel and polypropylene fibres, Journal of Cleaner Production https://doi.org/10.1016/j.jclepro.2020.120914

[29]John S. Lawler1; Davide Zampini2; and Surendra P. Shah3 Microfiber and Macrofiber Hybrid Fiber-Reinforced Concrete Journal of materials in civil engineering ( asce I september/october 2005 / 595https://doi.org/10.1061/(ASCE)0899-1561(2005)17.5(595)

[30]Karbhari VM, Chin J, Hunston D, Benmokrane B, Juska T, Morgan R, et al. Durability gap analysis for fiber-reinforced polymer composites in civil infrastructure. J Compos Constr 2003;7(3):238-47. DOI:10.1061/(ASCE)1090-0268(2003)7:3(238)

[31] Karbhari VM, Zhao L. Issues related to composite plating and environmental exposure effects on composite-concrete interface in external strengthening. Compos Struct 1997;40(34):293-304. https://doi.org/10.1016/S0263-8223(98)00031-2 
[32]Khin T. Soe, Y.X. Zhang, L.C. Zhang, Material properties of a new hybrid fibrereinforced engineered cementitious composite, Constr. Build. Mater. 43 (2013) 399-407 https://doi.org/10.1016/j.conbuildmat.2013.02.021

[33]Kou SC, Poon CS (2015) Effect of the quality of parent concrete on the properties of high performance recycled aggregate concrete. Constr Build Mater 77:501-508 DOI:10.1016/j.conbuildmat.2014.12.035.

[34]Li VC, Maalej M, Hashida T (1994) Experimental determination of the stress-crack opening relation in fibrecementitious composites with a crack-tip singularity. J Mater Sci 29(10):2719-2724. https://doi.org/10.1007/BF00356823

[35]Libo Yan, NawawiChouw, Sustainable Concrete and Structures with Natural Fiber Reinforcements, Infrastructure Corrosion and Durability - Sustainable Study, OMICS Group eBooks, 2014

[36]Luo X, Sun W, Chan SYN (2001) Steel fiber reinforced high-performance concrete: a study on the mechanical properties and resistance against impact. Mater Struct 34(3):144149. https://doi.org/10.1007/BF02480504

[37]M. Jamshidi, M. Karimi, Characterization of polymeric fibers as reinforcements of cement-based composites, J. Appl. Polym. Sci. 115 (5) (2010) 2779-2785.

DOI: $\underline{10.1002 / a p p .30302}$

[38]Machine Hsie, ChijenTu, P.S. Song Mechanical properties of polypropylene hybrid fiberreinforced concrete, Materials Science and Engineering A DOI:10.1016/j.msea.2008.05.037

[39]Maya Jacob John, Rajesh D. Anandjiwala, Recent developments in chemical modification and characterization of natural fiber-reinforced composites, Polym. Compos. (2008) 187-207DOI:10.1002/pc.20461

[40]Mazloom M, Ramezanianpour AA, Brooks JJ (2004) Effect of silica fume on mechanical properties of high-strength concrete. CemConcr Compos 26(4):347-357

https://doi.org/10.1016/S0958-9465(03)00017-9 